\title{
Privilege-Seeking Activities in Organizational Politics and Its Effect on More Productive Employees
}

Gil S. Epstein ${ }^{i}$

Department of Economics

Bar-Ilan University, Israel And

CReAM London and IZA Bonn

Bruce C. Herniter

College of Business and Management

DeVry University

North Brunswick, NJ USA 


\title{
Privilege-Seeking Activities in Organizational Politics and Its Effect on More Productive Employees
}

\begin{abstract}
The ability to accurately evaluate an employee would seem to be a key activity in managing Information Technology (IT). Yet, workers may engage in dishonest and misleading behavior, which distort the evaluation, a variation of organizational politics. Why would they do so? One hypothesis is that "privilege-seeking", that is, managing one's managers (also called "rentseeking", "management relations", or "organizational politics"), can be used by a worker to misrepresent his actual contribution. These activities lead to a reduction in productivity and consequently to a loss of profits. Management may decrease the firm's losses by engaging in costly monitoring activities. It is paradoxical that a behavior with such negative consequences is tolerated. A model is developed to show that an organization should be composed of employees with different levels of productivity; moreover, it may be optimal for the organization to have some employees who are good at privilege-seeking activities, forcing the remaining workers to invest in productive activities. This contradicts existing theory that unequal compensation should be less motivating and the remaining workers less productive.
\end{abstract}

Keywords: Employee evaluation, equity theory, influence costs, management relations, multiple agent model, monitoring, Nash equilibrium, privilege-seeking activities, rent, rent-seeking 


\section{INTRODUCTION}

Many organizations have difficulty assessing their employees' contributions to the total output and profit. For example, when a salesperson convinces a customer to buy a certain product, the actual purchase may be made through the local distributor. However, the parent organization will find it hard to determine which of the two (salesperson or distributor) is responsible for the sale. This is also true when evaluating IT employees' contributions. While IT staff contribute to the infrastructure and have a strategic role in the organization, many of their activities do not contribute directly to revenue or measureable cost savings. In the economics literature, this is a well-known problem. Radner (1992) has written: "If we look at individuals in the firm, especially in the managing sector, it is rare that we find a person whose output can be realistically measured in money or any other one-dimensional variable".

Still, management would like to reward each worker as a direct function of his/her contribution to the profits of the organization. In response, non-financial measures of performance are used to evaluate employees. Various systems are used to allocate rewards based on these, often arbitrary, measures. Klein, Jiang and Sobol (2001) recommend the use of "specific, challenging, and meaningful performance measures". However well-designed, these metrics do not solve the problem of directly measuring employee contributions. A gap exists between management's desire to reward economically productive behavior and the ability to measure that behavior.

As defined by Drory and Romm (1990), organizational politics is the minimal combination of three elements: influence, informal means, and conflict. In this case, employees will be rewarded if they influence the perception of their performance so that their evaluation by management is improved; in other words, so they are credited with more impact on organizational success than they actually had. This can be done by formal or informal means. In doing so, employees will come into conflict with one another. Thus the opportunity arises for organizational politics to intrude upon the formal process of measuring employee contributions.

From the economic point of view, political behavior generates "influence costs" that have been defined by Milgrom and Robert (1992) as "The costs included in attempts to influence others' decisions in a self-interested fashion, in attempts to counter such influence activities by others, and by the degradation of the quality of decisions because of influence." In their book (pp. 192-193) the authors mention several items that represent influence costs, including:

1. expending resources trying to influence the manager to bring about unproductive interventions;

2. influencing the manager to intervene inappropriately; and

3. controlling these attempts to influence the manager.

Previous work by Milgrom and Roberts (1986) (1988) (1990) also discuss this phenomenon. 
Since the benefits rewarded by management are a limited resource, there is conflict among the employees as competition develops. There are several theories which may describe or explain the motivation for engaging in the competition.

Maslow's hierarchy of needs (Maslow, 1943) describes motivation as a series of needs, each building on the other: physiological, safety, love, esteem, and self-actualization. Self-esteem may be a factor that directly relates to compensation. Maslow includes "respect from others" in his definition of the term (p. 381). In contemporary society, compensation is often a source of self-esteem. However, it is not clear what the bounds of that compensation should be.

Equity Theory addresses compensation directly. Individuals compare their worth against others. Adams (1963) (1965) proposed that the ratio of outcomes (O) to inputs (I) is what people use to compare themselves to others. The outcomes can be the pay received and the input is the time and effort expended. When an employee perceives that his or her ratio is lower than the norm, then he or she may feel underpaid. The employee may respond in a number of ways to try to increase the ratio, including:

- reducing input by decreasing the quantity of their output

- reducing input by decreasing the quality of their output

- increasing outcome

- changing their own perception of their outcomes and inputs

- leaving the field

- influencing the realities and perceptions of the outcomes and inputs of other employees

In the context of equity theory, action to influence the manager is simply another way to change the outcomes of an employee and increase the ratio of outcomes to inputs.

Tullock (1967) first investigated this attempt to influence to gain reward and resources, though it was named "rent seeking" by Krueger (1974). A more recent, and perhaps more descriptive term, is "privilege-seeking" (Tullock, 1980). Examples of privilege-seeking in the public sphere include lobbying for special tax breaks, regulatory exemptions, subsidies, and other special treatment. In the political context, the negative implications of privilege-seeking (or rent-seeking) have been a weapon used to argue against regulation, social programs, and tariffs; it has become synonymous with "waste".

In this paper we assume that the "rent" collected by the worker is in the form of higher compensation. We apply "influence costs" within an analytical model and query how the worker allocates his/her time and how the manager should allocate resources for controlling and minimizing influence costs. The framework for this model is a privilege-seeking contest in which the workers compete for their share of the "pie". Moreover, we look at the composition of the workforce that should exist in order to decrease these negative activities.

\section{THE APPROACH}

In the privilege-seeking contest presented in this paper, each worker is limited in the total amount of time that can be spent in privilege-seeking activities and real production. The more a worker invests in order to try and receive a larger portion of the pie (that is, collect the "rent"), the less time he will have to spend in real productive activities and thus decrease the total output 
of the organization. Management has two principal tools to manage privilege-seeking. First, it may limit the time managers give to workers during which privilege-seeking takes place. Second, it can monitor its workers to decrease the uncertainty regarding the workers' contribution to the profits of the organization. Unfortunately, monitoring is costly. Our model takes both into account.

\section{Monitoring}

Our approach can be analyzed within the framework of the principal agent problem. In this classic problem, the "principal" is the manager or supervisor and the "agent" is the employee or worker. There are two cases, the single agent and the multiple agent case. At issue in the single agent case is the development of a contract that will best motivate both the agent (worker or employee) and the principal (manager or supervisor). The problem of asymmetric information, where one side has more information than the other, usually exists. Spier explains that such asymmetry can lead to contractual incompleteness (Spier, 1992). An optimal contract, however, does not solve all the problems faced by both involved sides. In particular, an optimal contract does not eliminate the need for management to monitor employees and does not prevent privilege-seeking by workers. Milgrom (1988) suggests an "optimal contract" model and shows that even when this exists, both sides invest in attempts to influence decision making in the organization. He examines the effect that time spent on trying to influence decisions has on total output, and shows the conditions under which such efforts are efficient. This situation leads to the diverting of human resources from production to bargaining.

Furthermore, contracts do not eliminate the fact that principals must engage in monitoring. In general, the theory claims that monitoring increases the effort exerted by the agent (Frey, 1993). The answer to the basic question of whether to invest in monitoring depends on the expected utility versus cost (Jost, 1991). For the multiple agent case, Bohn (1987) deals with a similar question in which there are a large number of agents for every principal. Bohn shows that monitoring can be made efficient by changing the organization's structure into a hierarchy.

The monitoring method is itself a decision variable. Radner and Rothschild (1975) mention various possible policies that may be used by a decision maker who must determine his preferred order regarding different projects that are being processed and require his attention.

\section{Limiting time managers give to workers: the queue}

To reiterate, monitoring is meant to provide managers with information, but it requires meetings to gather information. Time thus becomes a resource to be allocated and can be a management tool. Epstein and Spiegel (1997) presented a similar type of problem in which the manager does not know the exact productivity level of workers and assumes that the workers' time includes meeting the management for briefings, advice, and approval of new ideas. In such meetings the management may also be called upon to solve problems that are beyond the employees' authority. At the same time, meetings become the management's main source of information concerning its employees' productivity. The management's assessments can be based on the problems brought before it by employees, as well as on their ideas and initiative. The author's model a workers' queue waiting for the management's attention. The main method used by the management to decrease the different type of externalities (i.e., rents) is via the time the workers have to wait for their appointment. In effect, a queue is established for workers waiting for 
meetings with management. The queue is to the benefit of management because it forces competition among workers for management face time (i.e., meetings). Thus, management recovers some of the "rent". In this model, a simple privilege-seeking game is setup instead of a queue to simulate the competition for time with management.

In this paper we set up a privilege-seeking competition in which the level of monitoring by the manager determines the total size of the prizes, while a queue for management time is established for the workers. We examine the relationship between the variance of workers' productivity and the organization's profit. In the following section we present the detailed model that is then followed by conclusions.

\section{THE MODEL}

We describe a multiple agent model that consists of two workers (agents or employees) and a manager (principal or supervisor). The manager does not know the exact productivity level of the workers. Information asymmetry exists because agents know the level of their productivity while the principal does not. Employees who may make false presentations regarding ideas and future plans can exploit this situation - in other words, spend time in privilege-seeking activities and may increase their income beyond their real contribution to the organizations production.

Each individual worker has an endowment of labor time normalized to one (or unity), which is allocated between productive activities $A_{i}$, and time $L_{i}$ spent in privilege-seeking activities, i.e., lobbying activities: $:^{\text {ii }}$

$$
A_{i}+L_{i}=1
$$

Where

$A_{i}=$ The proportion of work-time that worker $i$ is engaged in productive activities

$$
L_{i}=\text { The proportion of work-time that worker } i \text { is engaged in privilege-seeking activities }
$$

Assume both workers are equally efficient at privilege-seeking, but one worker is better at real productive activities than the other worker. That first worker has a comparative advantage at productive activities. So, when the two workers compete against one another for their share of the rewards, the first worker should specialize in productive activities while the second worker should specialize in privilege-seeking activities. For purposes of our model, we normalize the absolute efficiency in privilege-seeking activities to unity. Hence $w_{i}$ defines both the absolute and relative productive efficiency for one unit of time. It is assumed that the wage is competitively determined per efficiency-normalized unit of labor supplied.

The workers total contribution to the organization's output is denoted by:

$$
q_{i}=w_{i} A_{i}
$$

Using (1) this becomes: 
$q_{i}=w_{i}\left(1-L_{i}\right)$

Where

$q_{i}=$ Worker $i$ 's real contribution to the organization's output

$w_{i}=$ Worker $i$ 's productive efficiency for one unit of time

The same equation will hold if $j$ is substituted for $i$ :

$$
q_{j}=w_{j}\left(1-L_{j}\right)
$$

For reasons of exposition, we review an organization in which there are two workers and one manager. ${ }^{\text {iii }}$ Worker $i$ 's income for a given period will be denoted by $X_{i}$, which constitutes a percentage $\alpha$ (where $0<\alpha<1$ ) of the total perceived contribution to output of worker $i$ as assessed by the manager. The manager's assessment of a certain employee's production consists of the real production $q_{i}()$, plus a "false" production $f_{i}()$, which the manager believes has been produced by the worker. This false production is a function of privilege-seeking activities engaged in by the workers $i$ and $j$. Thus,

$$
X_{i}=\alpha\left(q_{i}+f_{i}\right)
$$

Where

$$
0<\alpha<1
$$

$X_{i}=$ Worker $i$ 's income for a given period

Using equation (1) we can write

$$
X_{i}=\alpha\left\{w_{i}\left(1-L_{i}\right)+f_{i}\left(L_{i}, L_{j}\right)\right\}
$$

Where for each worker $i$

$X_{i}=$ Income for a given period

$\alpha=$ Proportion of total perceived contribution to output for a period

$w_{i}=$ Worker $i$ 's productive efficiency for one unit of time

$f_{i}\left(L_{i}, L_{j}\right)=$ Imaginary production (or output) which the manger is falsely led to believe has been produced by worker $i$.

$L_{i}=$ The proportion of privilege-seeking activities engaged in by worker $i$ 


$$
L_{j}=\text { The proportion of privilege-seeking activities engaged in by worker } j
$$

We now move on to specifying $f_{i}\left(L_{i}, L_{j}\right)$.

The function $f_{i}\left(L_{i}, L_{j}\right)$ represents imaginary output which is positively affected by $L_{i}$ : investing more time in privilege-seeking activities (management relations) increases the employee's spurious contribution to production and as a result increases his reward. This assumption allows us to suppose that $L_{j}$, time devoted by worker $j$ to privilege-seeking activities (management relations), will negatively affect the reward to worker $i$ assuming, obviously, that the reward for spurious production is relatively stable.

We can think of the privilege-seeking activities as a contest between the workers competing for the share of output where the manager cannot determine the production level of each worker. Our contest is a variant of the type of activity described in the privilege-seeking literature (see Nitzan (1994) for a comprehensive survey). In such a contest, $f_{i}\left(L_{i}, L_{j}\right)$ is the contest success function (defined as the probability that worker $i$ is going to "win" the game).

We require a specification for a contest-success function (see Hirshleifer (1989)) and opt here for a popular choice, that of Tullock (1980), which has a natural probabilistic interpretation (see also (Epstein \& Nitzan, 2007, p. Chapter 16). Prospects of success improve the more an individual has contributed to the contest relative to the total value of the resources allocated (in contrast to the type of function described by Hillman and Riley (1989) where the highest bidder wins). The probability of worker $i$ winning the contest while competing against worker $j$ is based on the proportion of privilege-seeking activities engaged in by both the worker $i$, and his rival, worker $j$. The pairwise probability between the two workers is:

$$
\operatorname{Prob}_{i}\left(L_{i}, L_{j}\right)=\frac{L_{i}}{L_{i}+L_{j}} \text {, where } i \neq j
$$

Moreover, we assume that each worker gets a share of the total amount of income when the manager cannot determine the productive level of each worker:

$$
f_{i}\left(L_{i}, L_{j}\right)=\left(\frac{L_{i}}{L_{i}+L_{j}}-\frac{L_{j}}{L_{i}+L_{j}}\right) v
$$

Where $v=$ the level of income produced by the workers.

An implication of the above equation is that the total amount of transfers between any two workers is zero. One worker's gain in perceived imaginary production is another's loss:

$$
\sum_{i=1}^{2} f_{i}\left(L_{i}, L_{j}\right)=0 .
$$

Equation (6) tells us that privilege-seeking is a zero-sum game among the workers; all gains by one worker claiming imaginary output are offset by losses of another worker. This means that the workers can only "steal" from each other and not from the manager. ${ }^{\text {iv }}$ Notice that a worker who engages in privilege-seeking is not harmed by that individual decision. As worker $i$ 
increases his level of privilege-seeking activities $\left(L_{i}\right)$, he is rewarded by being credited by the manager with more perceived production. Since this perceived production is the sum of $q_{i}+f_{i}$, he is effectively increases his imaginary output $f_{i}$. A worker $i$ can then maximize his reward by increasing his privilege-seeking activities, so the first derivative of his imaginary production with respect to his own privilege-seeking activities is always positive:

$$
\frac{\partial f_{i}\left(L_{i}, L_{j}\right)}{\partial L_{i}}=\frac{2 L_{j}}{\left(L_{i}+L_{j}\right)^{2}} v>0
$$

On the other hand, a worker is harmed by the privilege-seeking activities of other workers. As worker $j$ increases his level of privilege-seeking activities $\left(L_{j}\right)$, the reward of worker $i$ decreases; the first derivative of his imaginary production with respect to another's privilegeseeking activities is always negative:

$$
\frac{\partial f_{i}\left(L_{i}, L_{j}\right)}{\partial L_{j}}=\frac{-2 L_{i}}{\left(L_{i}+L_{j}\right)^{2}} v<0
$$

Each worker maximizes his expected income by determining his level of privilege-seeking activities. Since each worker must take into consideration the privilege-seeking activities of the other workers, his expected income $X_{i}$ is determined by a Nash equilibrium (Nash, 1950) (Nash, 1951). The first order condition for worker number $j$ is:

$$
\frac{\partial X_{j}}{\partial L_{j}}=\alpha\left(-w_{j}+\frac{2 L_{i}}{\left(L_{i}+L_{j}\right)^{2}} v\right)=0 .
$$

From which we derive:

$$
w_{j}=2 \frac{L_{i}}{\left(L_{i}+L_{j}\right)^{2}} v
$$

The same equation will hold if the indices $i$ and $j$ are switched:

$$
w_{i}=2 \frac{L_{j}}{\left(L_{i}+L_{j}\right)^{2}} v
$$

In order to gain a better understanding of the results, let us look at the ratio of these activity levels for both employees. From (8b) and $\left(8 b^{\prime}\right)$ we derive that:

$$
\frac{L_{j}}{L_{i}}=\frac{w_{i}}{w_{j}}
$$

And

$$
L_{i}=L_{j} \frac{w_{j}}{w_{i}}
$$


This ratio indicates that the more worker $i$ specializes in production, the more the other worker, $j$, specializes in privilege-seeking activities. Using (9a) to substitute for $L_{i}$ in (8b) we derive

$$
L_{j}=2 \frac{w_{i}}{\left(w_{i}+w_{j}\right)^{2}} v .
$$

Similarly,

$$
L_{i}=2 \frac{w_{j}}{\left(w_{i}+w_{j}\right)^{2}} v .
$$

It is clear that the second order conditions hold. In addition, it has the form of a Nash Equilibrium. Moreover, we can see that $f_{j}$, the imaginary output of worker $j$, is a success function (defined as the probability that worker $j$ is going to "win" the game). Introducing (10a) and (10b) into (5), we calculate the success function as:

$$
f_{j}\left(L_{i}, L_{j}\right)=\frac{w_{i}-w_{j}}{w_{i}+w_{j}} \nu .
$$

The interesting question in this context is: who invests more in privilege-seeking activities, the more or the less productive worker? We may conclude from the above two equations that:

\section{Proposition 1:}

Less productive workers invest more time in privilege-seeking activities and have a higher probability of increasing their income from fictitious productive activities. ${ }^{\mathrm{v}}$

\section{Monitoring}

A worker's compensation is usually tied to a manager's assessment of his or her production (or output). Since the manager has incomplete information, what the manager knows is the perceived output. To reiterate our assumption from Equation (3a), each worker receives a proportion, $\alpha$, of his perceived production ${ }^{\mathrm{vi}}$. The manager can invest in monitoring in order to decrease the amount of transfers between workers. Monitoring workers increases the manager's knowledge of the contributions of each of them. This decreases the uncertainty and the amount of income transferred between workers. Notice that as the value of total transfers decreases, $v$, the levels of the privilege-seeking activities decrease and thus the total output of the organization increases.

We denote the level of monitoring of the manager by $m$, thus the total amount of income which the workers compete for is given by $v(m) . f$, the imaginary output, decreases with an increase in the level of monitoring $m$.

The manager maximizes the organization's profits by determining the optimal level of monitoring. Assuming for simplicity that prices are set at unity and the organization's profits are equal to the organization's net output. ${ }^{\text {vii }}$ Therefore, that net output is the sum of the worker's real output, minus the sum of the worker's income minus the cost of monitoring as shown: 
$Q\left(L_{i}, L_{j}\right)=q_{i}+q_{j}-\left(X_{i}+X_{j}\right)-c m$

Where, as before,

$Q=$ The organization's profit

$L_{i}=$ The proportion of privilege-seeking activities engaged in by worker $i$

$q_{i}=$ Worker $i$ 's real contribution to the organization's output

$X_{i}=$ Worker $i$ 's income for a given period

Also,

$$
\begin{aligned}
& \mathrm{c}=\text { the marginal cost of a unit of monitoring } \\
& \mathrm{m}=\text { the level of monitoring }
\end{aligned}
$$

Substituting equation (3a), we come to:

$$
Q\left(L_{i}, L_{j}\right)=q_{i}+q_{j}-\left(\alpha_{i}\left(q_{i}+f_{i}\right)+\alpha_{j}\left(q_{j}+f_{j}\right)\right)-c m
$$

Where $\alpha=$ Proportion of total perceived contribution to output for a period

Assuming that proportions $\alpha_{i}$ and $\alpha_{j}$ are the same value, then it follows:

$$
Q\left(L_{i}, L_{j}\right)=q_{i}+q_{j}-\alpha\left(\left(q_{i}+f_{i}\right)+\left(q_{j}+f_{j}\right)\right)-c m
$$

Using (5) and substituting the optimal level $q$ (from ( $2 b)$ and (2b’)) for privilege-seeking activities by the workers as determined in the Nash equilibrium equations (10a) and (10b), we derive that the profit of the manager is:

$$
\begin{aligned}
& Q\left(L_{i}^{*}, L_{j}^{*}\right)=(1-\alpha) w_{j}\left(1-2 \frac{w_{i}}{\left(w_{i}+w_{j}\right)^{2}} v(m)\right) \\
&+(1-\alpha) w_{i}\left(1-2 \frac{w_{j}}{\left(w_{i}+w_{j}\right)^{2}} v(m)\right)-c m \\
&=(1-\alpha)\left(w_{i}+w_{j}-4 \frac{w_{i} w_{j}}{\left(w_{i}+w_{j}\right)^{2}} v(m)\right)-c m .
\end{aligned}
$$


In order to get specific results we opt for a specific formulation for the monitoring function. We assume that $v(m)=\frac{a}{m}$, i.e., as the level of monitoring increases, the total pie that the workers can compete for decreases.

The first order conditions for maximization of the organization's profits are:

$$
\frac{\partial Q}{\partial m}=4(1-\alpha) \frac{w_{i} w_{j}}{\left(w_{i}+w_{j}\right)^{2}} \frac{a}{m^{2}}-c=0
$$

It is clear that the second order conditions hold.

Solving this we obtain:

$$
m=\sqrt{4(1-\alpha) \frac{w_{i} w_{j}}{\left(w_{i}+w_{j}\right)^{2}} \frac{a}{c}}
$$

As we can see the optimal level of monitoring, $\mathrm{m}$, decreases with an increase in its costs. We now look at what happens to the level of monitoring as worker $i$ becomes more productive than worker $\mathrm{j}\left(\right.$ i.e., $\left.w_{i}>w_{j}\right)$. viii

$$
\frac{\partial m}{\partial w_{i}}=\frac{1}{2} \frac{w_{j}\left(w_{j}^{2}-w_{i}^{2}\right)}{\left(w_{i}+w_{j}\right)^{4}} \sqrt{4(1-\alpha) \frac{a}{c} \frac{\left(w_{i}+w_{j}\right)^{2}}{w_{i} w_{j}}}<0
$$

From (16) we see that a) as the level of productivity of the more efficient worker increases, the level of monitoring decreases; and b) as the level of productivity of the less efficient worker increases, the level of monitoring increases. We may summarize this result in the following proposition:

\section{Proposition 2}

The level of monitoring decreases as the variance of productivity levels between the workers increases.

To illustrate this, let us look at a case where the sum of worker's productivities is constant, i.e., $w_{i}+w_{j}=k$. Notice that if the workers do not engage in privilege-seeking activities the total level of output of the organization is the sum of productivity levels. Increasing the productivity level of one worker while decreasing the other will result in a decrease of the level of monitoring:

$$
\left.\frac{\partial m}{\partial w_{i}}\right|_{w_{i}+w_{j}=k}=\frac{1}{2}\left(k-2 w_{i}\right) \sqrt{4(1-\alpha) \frac{a}{c} \frac{1}{k^{2} w_{i}\left(k-w_{i}\right)}}
$$

In other words, if the objective is to decrease the level of monitoring, the organization should be composed of different types of workers rather than the same type of workers. The less productive workers invest in privilege-seeking activities while the more productive workers 
invest in real output. Notice that, in a symmetric situation where all workers are identical, the transfers are zero (see (9) and (10)), while both workers are investing in privilege-seeking activities. We will return to this in the next section.

\section{Profits and the composition of the workforce}

As we saw in the previous section, the variance of the productivity levels of the workers determines the optimal monitoring level. In this section we will look at the organization's profits. In order to do so we first write the organization's profits as a function of the optimal production levels of the workers (equation (9)) and the optimal monitoring level (equation (15)). Thus by substituting (15) for (13) the organization's optimal profits are:

$$
Q\left(L_{i}^{*}, L_{j}^{*}\right)=(1-\alpha)\left(w_{i}+w_{j}\right)-4 \sqrt{a c(1-\alpha)} \frac{\sqrt{w_{i} w_{j}}}{w_{i}+w_{j}}
$$

We now address the following question. Are the profits of the organization larger when the workers are more or less productive? To answer this question let us look at the derivative of the profits of Equation (18) with regard to one of the productivity levels:

$$
\frac{\partial Q\left(L_{i}^{*}, L_{j}^{*}\right)}{\partial w_{i}}=(1-\alpha)-4 \sqrt{a c(1-\alpha)} \frac{w_{j} 0.5\left(w_{j}-w_{i}\right)}{\sqrt{w_{i} w_{j}}\left(w_{i}+w_{j}\right)^{2}}
$$

It is clear from the above equation that the organization's profits increase with the productivity level of the more efficient worker. This result is quite straightforward as it is clear that as the productivity level increases the profits should increase. In order to get a better look at this effect let us again hold constant the total productivity level of the workers (i.e., $w_{i}+w_{j}=$ $k)$.

$$
\left.\frac{\partial Q\left(L_{i}^{*}, L_{j}^{*}\right)}{\partial w_{i}}\right|_{w_{i}+w_{j}=k}=-\frac{4 \sqrt{a c(1-\alpha)}}{k} \frac{1}{2} \frac{k-2 w_{i}}{\sqrt{w_{i}\left(k-w_{i}\right)}}
$$

Notice that if the workers do not engage in privilege-seeking activities, then the organization's total level of output is the sum of productivity levels. As we can see from the above equation, the total profits increase if we increase the productivity level of the more efficient worker and decrease the productivity level of the less efficient worker.

\section{Proposition 3}

For a given mean level of production, the organization's profits increase as the variance of the productivity levels between the workers increase.

This proposition is not straightforward. It tells us that an organization which wants to increase its profits can do so by employing different types of workers. This enables specialization. The more efficient workers invest more time in real production while the less efficient invest in privilege-seeking activities. The manager is less concerned about this, even if 
the manager increases monitoring, he will only increase the less efficient workers' contribution to the organization's profits, and this is not very substantial anyway. Thus, it is better to have different types of workers in the organization: the profits increase and costly monitoring decreases.

\section{A worker as a substitute to monitoring}

The above results show that there is a substitution between the monitoring level and the variation in the productivity level of the workers. The question we ask in this section is whether it would be optimal to add an additional, less efficient worker so that he/she could specialize in privilegeseeking activities, forcing the other workers to decrease these activities and increase real production. Such a management strategy is implied by the results. To explore it however, we need to relax our earlier assumption that the manager cannot know any worker's level of privilege-seeking due to the asymmetry of information between the workers and the manager. If we relax that assumption, then we can postulate that the manager purposefully may add a "spy" who would give him information on the other workers through engaging in privilege-seeking activities.

In the case of three workers the income of a worker is given as:

$$
\begin{aligned}
& X_{i}=\alpha\left(q_{i}+f_{i}\right) \\
& X_{i}=\alpha\left(w_{i}\left(1-L_{i}\right)+f_{i}\left(L_{i}, L_{j}\right)\right),
\end{aligned}
$$

While, introducing the third worker $k$,

$$
\mathrm{f}_{\mathrm{i}}\left(\mathrm{L}_{\mathrm{i}}, \mathrm{L}_{\mathrm{j}}, \mathrm{L}_{\mathrm{k}}\right)=\left[\frac{2 \mathrm{~L}_{\mathrm{i}}}{\mathrm{L}_{\mathrm{i}}+\mathrm{L}_{\mathrm{j}}+\mathrm{L}_{\mathrm{k}}}-\frac{\mathrm{L}_{\mathrm{j}}}{\mathrm{L}_{\mathrm{i}}+\mathrm{L}_{\mathrm{j}}+\mathrm{L}_{\mathrm{k}}}-\frac{\mathrm{L}_{\mathrm{k}}}{\mathrm{L}_{\mathrm{i}}+\mathrm{L}_{\mathrm{j}}+\mathrm{L}_{\mathrm{k}}}\right] v
$$

And it holds that

$$
\sum_{i=1}^{3} f_{i}\left(L_{i}, L_{j}, L_{k}\right)=0
$$

Once again solving this problem as a Nash equilibrium we get that:

$$
L_{j}=8 \frac{\left(-w_{j}+w_{i}+w_{k}\right)}{\left(w_{j}+w_{i}+w_{k}\right)^{2}} \nu
$$

The conclusions for the case of two workers still hold true. The profits of the organization are:

$$
Q\left(L_{i}^{*}, L_{j}^{*}, L_{k}^{*}\right)=
$$




$$
\begin{aligned}
(1-\alpha) w_{i}[ & \left.1-8 \frac{-w_{i}+w_{j}+w_{k}}{\left(w_{i}+w_{j}+w_{k}\right)^{2}} v(m)\right] \\
& +(1-\alpha) w_{j}\left[1-8 \frac{-w_{j}+w_{i}+w_{k}}{\left(w_{i}+w_{j}+w_{k}\right)^{2}} v(m)\right] \\
& +(1-\alpha) w_{k}\left[1-8 \frac{-w_{k}+w_{i}+w_{j}}{\left(w_{i}+w_{j}+w_{k}\right)^{2}} v(m)\right] \\
& -c m
\end{aligned}
$$

Or to simplify:

$$
\begin{aligned}
& Q\left(L_{i}^{*}, L_{j}^{*}, L_{k}^{*}\right)= \\
& (1-\alpha) \times\left[\left(w_{i}+w_{j}+w_{k}\right)-8 \frac{-\left(w_{i}^{2}+w_{j}^{2}+w_{k}^{2}\right)+2 w_{i} w_{j}+2 w_{k} w_{j}+2 w_{k} w_{i}}{\left(w_{i}+w_{j}+w_{k}\right)^{2}} v(m)\right] \\
& -\mathrm{cm}
\end{aligned}
$$

The specific monitoring function of the third worker is denoted by $(m)=\frac{b}{m}$, where $a \leq b$; the level of monitoring for the first two workers continues to be described by $v(m)=\frac{a}{m}$. The condition $a \leq b$ guarantees that the level of monitoring for the three workers is greater than the level of monitoring for the first two workers, i.e., the total amount of transfers increases with the number of workers. In this case, the optimal level of monitoring occurs at the point where the profits are maximized. Maximum profits can be found by taking the first derivative of the profits $Q$ with respect to $m$ and setting it to zero. That yields an equation for $m$ :

$$
m=\sqrt{(1-\alpha) 8 \frac{-\left(w_{i}^{2}+w_{j}^{2}+w_{k}^{2}\right)+2 w_{i} w_{j}+2 w_{k} w_{j}+2 w_{k} w_{i}}{\left(w_{i}+w_{j}+w_{k}\right)^{2}} \frac{b}{c} .}
$$

In order to simplify this, let us assume that the two first workers are identical so that: $w_{i}=$ $w_{j}=w$ and $w_{k}=d w$. Thus, for $d<1$, the third worker is less productive than the other two. We will now calculate the organization's profits from the two original workers given the existence of a third worker. This profit is the result of both workers minus the cost of monitoring the three workers:

$$
\left.Q\left(L_{i}^{*}, L_{j}^{*}\right)\right|_{L_{k}^{*}}=2(1-\alpha) w-16 \frac{\sqrt{d}}{2+d} \sqrt{\frac{b c(1-\alpha)}{8(4-d)}}-\sqrt{8 \frac{b c(1-\alpha) d(4-d)}{(2+d)^{2}}}
$$

Notice that this is the organization's profit from two identical workers only, disregarding the direct contribution from worker number three. Of course, these profits do include the indirect contribution of the third worker via the privilege-seeking contest between the three. 
To see the indirect contribution to profits by third worker $k$, we compare Equations (27) and (18). Adding a third worker will increase the profits generated by the two original workers if it holds that:

$$
16 \frac{\sqrt{d}}{2+d} \sqrt{\frac{b c(1-\alpha)}{8(4-d)}}+\sqrt{8 \frac{b c(1-\alpha) d(4-d)}{(2+d)^{2}}}<2 \sqrt{(1-\alpha) a c}
$$

In the case where $a=b,(28)$ will hold true if $d \leq 0.3$. In the case where $b=\frac{3}{2} a$, then (28) holds true for $d<0.19$. In other words, adding a less efficient worker will increase the contributions of the more efficient workers to the organization's profits by forcing them to invest more in real production rather than in privilege-seeking activities. Notice that adding less efficient workers causes the more efficient ones to invest in real production, but the cost to the organization increases as a result of the need to increase the monitoring. We may summarize the results in the following proposition:

\section{Proposition 4}

The organization can increase its profits by adding less efficient workers that will force the more efficient ones to invest more time in real production rather than in privilegeseeking activities.

This result coincides with the former propositions as it tells us that it may be optimal for the organization to employ different types of workers rather than the same type. Moreover, it may well be optimal to add a less efficient worker, not for his direct contribution to production, but for his indirect contribution via the contest in the organization.

\section{CONCLUSIONS}

Organizations seek to reward their most productive workers in order to keep them in a competitive economy. Proposition 1 addresses that reward. To reward the right people at the right level, managers seek data and wish to minimize organizational politics. Since the information is incomplete, the productivity as they perceive it is what managers act upon. The perception by the manager of the productivity of each worker may be less than or greater than the employee's actual or real productivity. As the total productivity of the organization is known, any gain in the perceived productivity of one worker is taken out of the productivity of other workers; in other words, allocating productive activity among workers is a zero-sum game. In addition, a worker's time is limited, meaning that influence activities ("privilege-seeking" or "rent-seeking") takes away from productive time. Those who engage in influence activities are less productive than those who do not engage in it. Since a manager's time is also a limited resource, a competition for the manager's attention is set in motion. The employees who fair well at this competition are rewarded as they receive more credit than their output warrants, while employees who are more productive have less time to participate in this competition and therefore receive less credit than their output warrants.

Another way to look at the situation of these workers is through the lens of equity theory. The theory itself focuses on how an employee may address the fairness issue inherent in different 
ratios of outcomes to inputs. As mentioned in the introduction, there are many options for employees to correct the ratio, but not all of them produce immediate rewards for the productive employee. They may reduce their inputs through absenteeism. They may reduce the quality of their work, leaving the quantity the same. The more productive workers might change their own perceptions of their situation and conclude that the situation really is fair.

However, if the goal is simply to increase the outcome for the more productive employees, the options described by equity theory are different. To increase the outcome, the productive workers have the choice of increasing their inputs or trying to influence the manager into perceiving that their inputs have increased. If the productive workers are less successful at influence activities, then the alternative for them is to increase their productive activities.

This begs the question as to why the more productive workers would remain in an organization whose compensation practices they perceive as unfair. There are several possible answers. They might view the inequity as temporary and the organization will adjust situation given time. They might also believe that influencing the manager is simply part of the job and is a valid input.

For whatever reason, we propose that inequalities are inherent simply because of the lack of information available to the manager. Given that, Proposition 1 is consistent with what we think we "know", that people who are good at selling themselves get a payoff. Having employees with lower productivity but higher privilege-seeking activities looks like a poor human resources strategy. Monitoring employees should result in decreasing uncertainty and therefore limit the payoff to influence-seeking. It is interesting that (as summarized in our second proposition) the level of monitoring decreases not with increased productivity, but with increased variation in productivity among employees. Of even more interest is that the greater the variance among employees, the greater the profits for the organization (Proposition 3). In sum, as the variance in productivity increases, monitoring can drop and profits rise.

Managers are left with the question: besides hiring highly productive employees, is there anything else that can be done? Instead of letting go the less productive employees who engage in influence-seeking, organizations should recognize that they actually may help the effort. Proposition 4 indicates that good influence-seekers will force the more productive workers to even more real production. In fact, because of asymmetric information, management would need to increase monitoring to discover the influence-seekers. The cost of this additional monitoring may be detrimental to profits.

\section{WORKS CITED}

Adams, J. S. (1965). Inequity in Social Exchange. In L. Berkowitz, Advances in Experimental Psychology (pp. 267-299). New York, New York, USA: Academic Press.

Adams, J. S. (1963). Towards an understanding of inequity. The Journal of Abnormal and Social Psychology, 67 (5), 422-436. 
Bohn, H. (1987). "Monitoring Multiple Agents: The Role of Hierarchies. Journal of Economic Behavior and Organization , 8 (2), 279-305.

Drory, A., \& Romm, T. (1990). The Definition of Organizational Politics: A Review. Human Relations , 43 (11), 1133-1154.

Epstein, G. S. (1996). Changing a Decision Taken Under Incomplete Information During the Process of Execution. Journal of Economic Behavior and Organization , 29 (2), 323-329.

Epstein, G. S. (1996). The Extraction of a Natural Resource from Two Sites Under Uncertainty. Economics Letters , 51 (3), 309-313.

Epstein, G. S., \& Nitzan, S. (2007). Endogenous Public Policy and Contests. Berlin: SpringerVerlag.

Epstein, G. S., \& Spiegel, U. (1997). Monitoring within the Firm and Manager Relations. International Journal of the Economics of Business , 4 (1), 51-62.

Frey, B. S. (1993). Does Monitoring Increase Work Effort? The Rivalry with Trust and Loyalty. Economic Inquiry , 31 (4), 663-670.

Hillman, A. L., \& Riley, J. G. (1989). Politically Contestable Rents and Transfers. Economics and Politics , 1 (1), 17-39.

Hirshleifer, J. (1989). Conflict and Rent Seeking Success functions: Ratio Vs Difference Model of Relative Success. Public Choice , 63 (2), 101-112.

Jost, P. J. (1991). Monitoring in Principal Agent Relationships. Journal of Institutional and Theoretical Economics , 147 (3), 517-538.

Klein, G., Jiang, J. J., \& Sobol, M. G. (2001). A New View of IS Personnel Performance Evaluation. Communications of the ACM , 44 (6), 95-101.

Krueger, A. O. (1974). The Political Economy of the Rent-Seeking Society. The American Economic Review , 64 (3), 291-303.

Maslow, A. H. (1943). A Theory of Human Motivation. Psychological Review , 50 (4), 370-396.

Milgrom, P. R. (1988). Employment Contracts, Influence Activities, and Efficient Organization Design. Journal of Political Economy, 96 (1), 42-60.

Milgrom, P. R., \& Roberts, J. (1988). An Economic Approach to Influence Activities in Organizations. American Journal of Sociology, 94, S154-S179.

Milgrom, P. R., \& Roberts, J. (1990). Bargaining and Influence Costs and the Organization of Economic Activity. In J. Alt, \& K. Shepsle (Eds.), Perspectives on Positive Political Economy (pp. 57-89). New York, NY, USA: Cambridge University Press.

Milgrom, P. R., \& Roberts, J. (1992). Economics, Organization and Management. Prentice Hall. 
Milgrom, P. R., \& Roberts, J. (1986). Relying on the Information of Interested Parties. RAND Journal of Economics , 17, 18-32.

Nash, J. F. (1950). Equilibrium points in n-person games. Proceedings of the National Academy of Sciences , 36 (1), 48-49.

Nash, J. F. (1951). Non-Cooperative Games. The Annals of Mathematics , 54 (2), 286-295.

Nitzan, S. (1994). Modelling Rent-Seeking Contests. European Journal of Political Economy, 10, 41-60.

Radner, R. (1992). Hierarchy: The Economics of Managing. Journal of Economic Literature , 30 (3), 1382-1415.

Radner, R., \& Rothschild, M. (1975). On the allocation of effort. Journal of Economic Theory, 10 (3), 358-376.

Spier, K. E. (1992). Incomplete Contracts and Signaling. RAND Journal of Economics , 23 (3), 432-443.

Tullock, G. (1980). Efficient Rent Seeking. In J. M. Buchanan, R. D. Tollison, \& G. Tullock (Eds.), Toward a Theory of the Rent Seeking Society (pp. 97-112). College Station, Texas, USA: Texas A\&M University Press.

Tullock, G. (1967). The Welfare Costs of Tariffs, Monopolies, and Theft. Western Economic Journal , 5 (3), 224-232.

\footnotetext{
${ }^{\mathrm{i}}$ Financial support from the Adar Foundation of the Economics Department at Bar-Ilan University is gratefully acknowledged.

ii This assumption eliminates the need to refer to a particular period of time (hour, day week, month, etc.) and simplifies the mathematics.

iii All the results hold true for any number of workers (agents-employees).

iv Another model could be $f_{i}\left(L_{i}, L_{j}\right)=\frac{L_{i}}{L_{i}+L_{j}} v$. In this case the workers are "stealing" directly from the manager (as $\left.\sum_{i=1}^{2} f_{i}\left(L_{i}, L_{j}\right)=v\right)$. Both options give the same results. For convenience we opt for the first choice.

v I.e. $\frac{\partial \frac{L_{j}}{L_{i}}}{\partial w_{j}}<0, \frac{\partial \frac{L_{j}}{L_{i}}}{\partial w_{i}}>0, \frac{\partial L_{j}}{\partial w_{j}}<0, \frac{\partial L_{j}}{\partial w_{i}}>0, \frac{\partial f_{j}}{\partial w_{j}}<0$, and $\frac{\partial f_{j}}{\partial w_{i}}>0$.

${ }^{\text {vi }}$ That is, $0<\alpha<1$.

vii Setting prices to unity is a standard economic modeling technique. It eliminates the need to refer to a particular currency and simplifies the mathematics. This assumption has no effect on conclusions from the model.

viii These results may still hold when workers' output levels are random variables and the manager may change his decision as the information about the workers is revealed. See Epstein (Changing a Decision Taken Under Incomplete Information During the Process of Execution, 1996) (The Extraction of a Natural Resource from Two Sites Under Uncertainty, 1996) where conditions are generated about a decison maker who will not change his/her ruling in the process of execution even though new information is received.
} 


\section{Bar-Ilan University \\ Department of Economics \\ WORKING PAPERS}

1-01 The Optimal Size for a Minority

Hillel Rapoport and Avi Weiss, January 2001.

2-01 An Application of a Switching Regimes Regression to the Study of Urban Structure

Gershon Alperovich and Joseph Deutsch, January 2001.

3-01 The Kuznets Curve and the Impact of Various Income Sources on the Link Between Inequality and Development

Joseph Deutsch and Jacques Silber, February 2001.

4-01 International Asset Allocation: A New Perspective

Abraham Lioui and Patrice Poncet, February 2001.

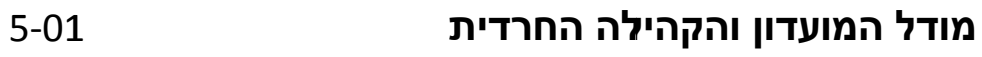

$$
\text { יעקב רוזנברג, פברואר } 2001 .
$$

6-01 Multi-Generation Model of Immigrant Earnings: Theory and Application Gil S. Epstein and Tikva Lecker, February 2001.

7-01 Shattered Rails, Ruined Credit: Financial Fragility and Railroad Operations in the Great Depression

Daniel A. Schiffman, February 2001.

8-01 Cooperation and Competition in a Duopoly R\&D Market

Damiano Bruno Silipo and Avi Weiss, March 2001.

9-01 A Theory of Immigration Amnesties

Gil S. Epstein and Avi Weiss, April 2001.

10-01 Dynamic Asset Pricing With Non-Redundant Forwards Abraham Lioui and Patrice Poncet, May 2001.

11-01 Macroeconomic and Labor Market Impact of Russian Immigration in Israel Sarit Cohen and Chang-Tai Hsieh, May 2001.

Electronic versions of the papers are available at http://www.biu.ac.il/soc/ec/wp/working_papers.html 
12-01 Network Topology and the Efficiency of Equilibrium Igal Milchtaich, June 2001.

13-01 General Equilibrium Pricing of Trading Strategy Risk Abraham Lioui and Patrice Poncet, July 2001.

14-01 Social Conformity and Child Labor Shirit Katav-Herz, July 2001.

15-01 Determinants of Railroad Capital Structure, 1830-1885 Daniel A. Schiffman, July 2001.

16-01 Political-Legal Institutions and the Railroad Financing Mix, 1885-1929 Daniel A. Schiffman, September 2001.

17-01 Macroeconomic Instability, Migration, and the Option Value of Education Eliakim Katz and Hillel Rapoport, October 2001.

18-01 Property Rights, Theft, and Efficiency: The Biblical Waiver of Fines in the Case of Confessed Theft

Eliakim Katz and Jacob Rosenberg, November 2001.

19-01 Ethnic Discrimination and the Migration of Skilled Labor Frédéric Docquier and Hillel Rapoport, December 2001.

1-02 Can Vocational Education Improve the Wages of Minorities and Disadvantaged Groups? The Case of Israel

Shoshana Neuman and Adrian Ziderman, February 2002.

2-02 What Can the Price Gap between Branded and Private Label Products Tell Us about Markups?

Robert Barsky, Mark Bergen, Shantanu Dutta, and Daniel Levy, March 2002.

3-02 Holiday Price Rigidity and Cost of Price Adjustment Daniel Levy, Georg Müller, Shantanu Dutta, and Mark Bergen, March 2002.

4-02 Computation of Completely Mixed Equilibrium Payoffs Igal Milchtaich, March 2002.

5-02 Coordination and Critical Mass in a Network Market - An Experimental Evaluation Amir Etziony and Avi Weiss, March 2002. 
6-02 Inviting Competition to Achieve Critical Mass

Amir Etziony and Avi Weiss, April 2002.

7-02 Credibility, Pre-Production and Inviting Competition in a Network Market Amir Etziony and Avi Weiss, April 2002.

8-02 Brain Drain and LDCs' Growth: Winners and Losers Michel Beine, Fréderic Docquier, and Hillel Rapoport, April 2002.

9-02 Heterogeneity in Price Rigidity: Evidence from a Case Study Using MicroLevel Data

Daniel Levy, Shantanu Dutta, and Mark Bergen, April 2002.

10-02 Price Flexibility in Channels of Distribution: Evidence from Scanner Data Shantanu Dutta, Mark Bergen, and Daniel Levy, April 2002.

11-02 Acquired Cooperation in Finite-Horizon Dynamic Games Igal Milchtaich and Avi Weiss, April 2002.

12-02 Cointegration in Frequency Domain Daniel Levy, May 2002.

13-02 Which Voting Rules Elicit Informative Voting? Ruth Ben-Yashar and Igal Milchtaich, May 2002.

14-02 Fertility, Non-Altruism and Economic Growth: Industrialization in the Nineteenth Century

Elise S. Brezis, October 2002.

15-02 Changes in the Recruitment and Education of the Power Elitesin Twentieth Century Western Democracies

Elise S. Brezis and François Crouzet, November 2002.

16-02 On the Typical Spectral Shape of an Economic Variable Daniel Levy and Hashem Dezhbakhsh, December 2002.

17-02 International Evidence on Output Fluctuation and Shock Persistence Daniel Levy and Hashem Dezhbakhsh, December 2002.

1-03 Topological Conditions for Uniqueness of Equilibrium in Networks Igal Milchtaich, March 2003.

2-03 Is the Feldstein-Horioka Puzzle Really a Puzzle? Daniel Levy, June 2003. 
3-03 Growth and Convergence across the US: Evidence from County-Level Data Matthew Higgins, Daniel Levy, and Andrew Young, June 2003.

4-03 Economic Growth and Endogenous Intergenerational Altruism Hillel Rapoport and Jean-Pierre Vidal, June 2003.

5-03 Remittances and Inequality: A Dynamic Migration Model Frédéric Docquier and Hillel Rapoport, June 2003.

6-03 Sigma Convergence Versus Beta Convergence: Evidence from U.S. CountyLevel Data

Andrew T. Young, Matthew J. Higgins, and Daniel Levy, September 2003.

7-03 Managerial and Customer Costs of Price Adjustment: Direct Evidence from Industrial Markets

Mark J. Zbaracki, Mark Ritson, Daniel Levy, Shantanu Dutta, and Mark Bergen, September 2003.

8-03 First and Second Best Voting Rules in Committees

Ruth Ben-Yashar and Igal Milchtaich, October 2003.

9-03 Shattering the Myth of Costless Price Changes: Emerging Perspectives on Dynamic Pricing

Mark Bergen, Shantanu Dutta, Daniel Levy, Mark Ritson, and Mark J. Zbaracki, November 2003.

1-04 Heterogeneity in Convergence Rates and Income Determination across U.S. States: Evidence from County-Level Data

Andrew T. Young, Matthew J. Higgins, and Daniel Levy, January 2004.

2-04 "The Real Thing:" Nominal Price Rigidity of the Nickel Coke, 1886-1959 Daniel Levy and Andrew T. Young, February 2004.

3-04 Network Effects and the Dynamics of Migration and Inequality: Theory and Evidence from Mexico

David Mckenzie and Hillel Rapoport, March 2004.

4-04 Migration Selectivity and the Evolution of Spatial Inequality Ravi Kanbur and Hillel Rapoport, March 2004.

5-04 Many Types of Human Capital and Many Roles in U.S. Growth: Evidence from County-Level Educational Attainment Data

Andrew T. Young, Daniel Levy and Matthew J. Higgins, March 2004. 
6-04 When Little Things Mean a Lot: On the Inefficiency of Item Pricing Laws Mark Bergen, Daniel Levy, Sourav Ray, Paul H. Rubin and Benjamin Zeliger, May 2004.

7-04 Comparative Statics of Altruism and Spite Igal Milchtaich, June 2004.

8-04 Asymmetric Price Adjustment in the Small: An Implication of Rational Inattention

Daniel Levy, Haipeng (Allan) Chen, Sourav Ray and Mark Bergen, July 2004.

1-05 Private Label Price Rigidity during Holiday Periods Georg Müller, Mark Bergen, Shantanu Dutta and Daniel Levy, March 2005.

2-05 Asymmetric Wholesale Pricing: Theory and Evidence Sourav Ray, Haipeng (Allan) Chen, Mark Bergen and Daniel Levy, March 2005.

3-05 Beyond the Cost of Price Adjustment: Investments in Pricing Capital Mark Zbaracki, Mark Bergen, Shantanu Dutta, Daniel Levy and Mark Ritson, May 2005.

4-05 Explicit Evidence on an Implicit Contract Andrew T. Young and Daniel Levy, June 2005.

5-05 Popular Perceptions and Political Economy in the Contrived World of Harry Potter

Avichai Snir and Daniel Levy, September 2005.

6-05 Growth and Convergence across the US: Evidence from County-Level Data (revised version)

Matthew J. Higgins, Daniel Levy, and Andrew T. Young, September 2005.

1-06 Sigma Convergence Versus Beta Convergence: Evidence from U.S. CountyLevel Data (revised version)

Andrew T. Young, Matthew J. Higgins, and Daniel Levy, June 2006.

2-06 Price Rigidity and Flexibility: Recent Theoretical Developments Daniel Levy, September 2006.

3-06 The Anatomy of a Price Cut: Discovering Organizational Sources of the Costs of Price Adjustment

Mark J. Zbaracki, Mark Bergen, and Daniel Levy, September 2006. 
4-06 Holiday Non-Price Rigidity and Cost of Adjustment

Georg Müller, Mark Bergen, Shantanu Dutta, and Daniel Levy.

September 2006.

2008-01 Weighted Congestion Games With Separable Preferences

Igal Milchtaich, October 2008.

2008-02 Federal, State, and Local Governments: Evaluating their Separate Roles in US Growth

Andrew T. Young, Daniel Levy, and Matthew J. Higgins, December 2008.

2008-03 Political Profit and the Invention of Modern Currency

Dror Goldberg, December 2008.

2008-04 Static Stability in Games

Igal Milchtaich, December 2008.

2008-05 Comparative Statics of Altruism and Spite

Igal Milchtaich, December 2008.

2008-06 Abortion and Human Capital Accumulation: A Contribution to the Understanding of the Gender Gap in Education

Leonid V. Azarnert, December 2008.

2008-07 Involuntary Integration in Public Education, Fertility and Human Capital

Leonid V. Azarnert, December 2008.

2009-01 Inter-Ethnic Redistribution and Human Capital Investments

Leonid V. Azarnert, January 2009.

2009-02 Group Specific Public Goods, Orchestration of Interest Groups and Free Riding

Gil S. Epstein and Yosef Mealem, January 2009.

2009-03 Holiday Price Rigidity and Cost of Price Adjustment

Daniel Levy, Haipeng Chen, Georg Müller, Shantanu Dutta, and Mark Bergen, February 2009.

2009-04 Legal Tender

Dror Goldberg, April 2009.

2009-05 The Tax-Foundation Theory of Fiat Money

Dror Goldberg, April 2009. 
2009-06 The Inventions and Diffusion of Hyperinflatable Currency

Dror Goldberg, April 2009.

2009-07 The Rise and Fall of America's First Bank

Dror Goldberg, April 2009.

2009-08 Judicial Independence and the Validity of Controverted Elections

Raphaël Franck, April 2009.

2009-09 A General Index of Inherent Risk

Adi Schnytzer and Sara Westreich, April 2009.

2009-10 Measuring the Extent of Inside Trading in Horse Betting Markets

Adi Schnytzer, Martien Lamers and Vasiliki Makropoulou, April 2009.

2009-11 The Impact of Insider Trading on Forecasting in a Bookmakers' Horse Betting Market

Adi Schnytzer, Martien Lamers and Vasiliki Makropoulou, April 2009.

2009-12 Foreign Aid, Fertility and Population Growth: Evidence from Africa Leonid V. Azarnert, April 2009.

2009-13 A Reevaluation of the Role of Family in Immigrants' Labor Market Activity: Evidence from a Comparison of Single and Married Immigrants Sarit Cohen-Goldner, Chemi Gotlibovski and Nava Kahana, May 2009.

2009-14 The Efficient and Fair Approval of "Multiple-Cost-Single-Benefit" Projects Under Unilateral Information Nava Kahanaa, Yosef Mealem and Shmuel Nitzan, May 2009.

2009-15 Après nous le Déluge: Fertility and the Intensity of Struggle against Immigration

Leonid V. Azarnert, June 2009.

2009-16 Is Specialization Desirable in Committee Decision Making?

Ruth Ben-Yashar, Winston T.H. Koh and Shmuel Nitzan, June 2009.

2009-17 Framing-Based Choice: A Model of Decision-Making Under Risk

Kobi Kriesler and Shmuel Nitzan, June 2009.

2009-18 Demystifying the 'Metric Approach to Social Compromise with the Unanimity Criterion'

Shmuel Nitzan, June 2009. 
2009-19 On the Robustness of Brain Gain Estimates

Michel Beine, Frédéric Docquier and Hillel Rapoport, July 2009.

2009-20 Wage Mobility in Israel: The Effect of Sectoral Concentration

Ana Rute Cardoso, Shoshana Neuman and Adrian Ziderman, July 2009.

2009-21 Intermittent Employment: Work Histories of Israeli Men and Women, 1983-1995

Shoshana Neuman and Adrian Ziderman, July 2009.

2009-22 National Aggregates and Individual Disaffiliation: An International Study

Pablo Brañas-Garza, Teresa García-Muñoz and Shoshana Neuman, July 2009.

2009-23 The Big Carrot: High-Stakes Incentives Revisited

Pablo Brañas-Garza, Teresa García-Muñoz and Shoshana Neuman, July 2009.

2009-24 The Why, When and How of Immigration Amnesties

Gil S. Epstein and Avi Weiss, September 2009.

2009-25 Documenting the Brain Drain of "la Crème de la Crème»: Three Case-Studies on International Migration at the Upper Tail of the Education Distribution

Frédéric Docquier and Hillel Rapoport, October 2009.

2009-26 Remittances and the Brain Drain Revisited: The Microdata Show That More Educated Migrants Remit More

Albert Bollard, David McKenzie, Melanie Morten and Hillel Rapoport, October 2009.

2009-27 Implementability of Correlated and Communication Equilibrium Outcomes in Incomplete Information Games Igal Milchtaich, November 2009.

2010-01 The Ultimatum Game and Expected Utility Maximization - In View of Attachment Theory

Shaul Almakias and Avi Weiss, January 2010.

2010-02 A Model of Fault Allocation in Contract Law - Moving From Dividing Liability to Dividing Costs

Osnat Jacobi and Avi Weiss, January 2010. 
2010-03 Coordination and Critical Mass in a Network Market: An Experimental Investigation

Bradley J. Ruffle, Avi Weiss and Amir Etziony, February 2010.

2010-04 Immigration, fertility and human capital: A model of economic decline of the West

Leonid V. Azarnert, April 2010.

2010-05 Is Skilled Immigration Always Good for Growth in the Receiving Economy?

Leonid V. Azarnert, April 2010.

2010-06 The Effect of Limited Search Ability on the Quality of Competitive Rent-Seeking Clubs

Shmuel Nitzan and Kobi Kriesler, April 2010.

2010-07 Condorcet vs. Borda in Light of a Dual Majoritarian Approach

Eyal Baharad and Shmuel Nitzan, April 2010.

2010-08 Prize Sharing in Collective Contests

Shmuel Nitzan and Kaoru Ueda, April 2010.

2010-09 Network Topology and Equilibrium Existence in Weighted Network Congestion Games

Igal Milchtaich, May 2010.

2010-10 The Evolution of Secularization: Cultural Transmission, Religion and Fertility Theory, Simulations and Evidence

Ronen Bar-El, Teresa García-Muñoz, Shoshana Neuman and Yossef Tobol, June 2010.

2010-11 The Economics of Collective Brands

Arthur Fishman, Israel Finkelstein, Avi Simhon and Nira Yacouel, July 2010.

2010-12 Interactions Between Local and Migrant Workers at the Workplace

Gil S. Epstein and Yosef Mealem, August 2010.

2010-13 A Political Economy of the Immigrant Assimilation: Internal Dynamics

Gil S. Epstein and Ira N. Gang, August 2010.

2010-14 Attitudes to Risk and Roulette

Adi Schnytzer and Sara Westreich, August 2010. 
2010-15 Life Satisfaction and Income Inequality

Paolo Verme, August 2010.

2010-16 The Poverty Reduction Capacity of Private and Public Transfers in Transition

Paolo Verme, August 2010.

2010-17 Migration and Culture

Gil S. Epstein and Ira N. Gang, August 2010.

2010-18 Political Culture and Discrimination in Contests

Gil S. Epstein, Yosef Mealem and Shmuel Nitzan, October 2010.

2010-19 Governing Interest Groups and Rent Dissipation

Gil S. Epstein and Yosef Mealem, November 2010.

2010-20 Beyond Condorcet: Optimal Aggregation Rules Using Voting Records

Eyal Baharad, Jacob Goldberger, Moshe Koppel and Shmuel Nitzan, December 2010.

2010-21 Price Points and Price Rigidity

Daniel Levy, Dongwon Lee, Haipeng (Allan) Chen, Robert J. Kauffman and Mark Bergen, December 2010.

2010-22 Price Setting and Price Adjustment in Some European Union

Countries: Introduction to the Special Issue

Daniel Levy and Frank Smets, December 2010.

2011-01 Business as Usual: A Consumer Search Theory of Sticky Prices and Asymmetric Price Adjustment

Luís Cabral and Arthur Fishman, January 2011.

2011-02 Emigration and democracy

Frédéric Docquier, Elisabetta Lodigiani, Hillel Rapoport and Maurice Schiff, January 2011.

2011-03 Shrinking Goods and Sticky Prices: Theory and Evidence

Avichai Snir and Daniel Levy, March 2011.

2011-04 Search Costs and Risky Investment in Quality

Arthur Fishman and Nadav Levy, March 2011. 
2011-05 To What Extent do Investors in a Financial Market Anchor Their Judgments? Evidence from the Hong Kong Horserace Betting Market Johnnie E.V. Johnson, Shuang Liu and Adi Schnytzer, March 2011.

2011-06 Attitudes to Risk and Roulette

Adi Schnytzer and Sara Westreich, March 2011.

2011-07 False Consciousness in Financial Markets: Or is it in Ivory Towers? Adi Schnytzer and Sara Westreich, March 2011.

2011-08 Herding in Imperfect Betting Markets with Inside Traders

Adi Schnytzer and Avichai Snir, March 2011.

2011-09 Painful Regret and Elation at the Track

Adi Schnytzer and Barbara Luppi, March 2011.

2011-10 The Regression Tournament: A Novel Approach to Prediction Model Assessment

Adi Schnytzer and Janez Šušteršič, March 2011.

2011-11 Shorting the Bear: A Test of Anecdotal Evidence of Insider Trading in Early Stages of the Sub-Prime Market Crisis

Les Coleman and Adi Schnytzer, March 2011.

2011-12 SP Betting as a Self-Enforcing Implicit Cartel

Adi Schnytzer and Avichai Snir, March 2011.

2011-13 Testing for Home Team and Favorite Biases in the Australian Rules Football Fixed Odds and Point Spread Betting Markets

Adi Schnytzer and Guy Weinberg, March 2011.

2011-14 The Impact of Insider Trading on Forecasting in a Bookmakers' Horse Betting Market

Adi Schnytzer, Martien Lamers and Vasiliki Makropoulou, March 2011.

2011-15 The Prediction Market for the Australian Football League

Adi Schnytzer, March 2011.

2011-16 Information and Attitudes to Risk at the Track

Adi Schnytzer and Sara Westreich, March 2011.

2011-17 Explicit Evidence on an Implicit Contract

Andrew T. Young and Daniel Levy, March 2011. 
2011-18 Globalization, Brain Drain and Development

Frédéric Docquier and Hillel Rapoport, March 2011.

2011-19 The Impact of Worker Effort on Public Sentiment Towards Temporary Migrants

Gil S. Epstein and Alessandra Venturini, April 2011.

2011-20 Animal Modeling of Earthquakes and Prediction Markets

Adi Schnytzer and Yisrael Schnytzer, May 2011.

2011-21 A Field Study of Social Learning

Arthur Fishman and Uri Gneezy, May 2011.

2011-22 MD Dialog on: Optimum Savings and Optimal Growth: the CassMalinvaud-Koopmans Nexus

Stephen E. Spear and Warren Young, May 2011.

2011-23 Privilege-Seeking Activities in Organizational Politics and Its Effect on More Productive Employees

Gil S. Epstein and Bruce C. Herniter, August 2011.

2011-24 Integrated Public Education, Fertility and Human Capital Leonid V. Azarnert, August 2011.

2011-25 Male vs. Female Guest-Worker Migration: Does it Matter for Fertility in the Source Country?

Leonid V. Azarnert, August 2011. 